\title{
The effect of palatability of protein source on dietary selection in dairy calves
}

\author{
E. K. Miller-Cushon, ${ }^{*}$ M. Terré, † T. J. DeVries, ${ }^{*}$ and A. Bach $† \ddagger^{1}$ \\ ${ }^{*}$ Department of Animal and Poultry Science, University of Guelph, Kemptville Campus, 830 Prescott Street, Kemptville, ON, K0G 1J0, Canada \\ †Department of Ruminant Production, IRTA (Institut de Recerca i Tecnologia Agroalimentàries), 08140 Caldes de Montbui, Spain \\ ‡ICREA (Institució Catalana de Recerca i Estudis Avançats), 08010 Barcelona, Spain
}

\begin{abstract}
Evidence has shown that soybean meal is perceived as more palatable than canola meal by dairy calves in short-term preference tests. This study evaluated the effect of protein source on longer-term dietary selection of dairy calves. In experiment 1, 40 Holstein bull calves $(11.4 \pm 4.3 \mathrm{~d}$ of age) were randomly assigned to 1 of 2 choice diets for 6 wk: base starter pellet (S; $12 \%$ crude protein; CP) and high-protein pellet (40\% CP) containing either (1) soybean meal (SB) or (2) canola meal (CM). In wk 7 to 8, all calves were offered a single pelleted diet containing the protein source to which they were previously exposed. In experiment 2, 22 Holstein bull calves $(9.9 \pm 4.6 \mathrm{~d}$ of age) were offered, for $6 \mathrm{wk}$, a choice of 2 mixed pelleted diets: (1) $70 \% \mathrm{~S}$ and $30 \% \mathrm{SB}$ (SB mix), or (2) $70 \% \mathrm{~S}$ and $30 \% \mathrm{CM}$ (CM mix). In wk 7 to 8 , calves were randomly assigned to 1 of 2 choice diets, as in experiment 1: (1) SB $+\mathrm{S}$, or (2) $\mathrm{CM}+\mathrm{S}$. All feeds were provided ad libitum. Calves received 6 $\mathrm{L} / \mathrm{d}$ of milk replacer $[0.75 \mathrm{~kg} / \mathrm{d}$ of dry matter $(\mathrm{DM})]$ for the duration of both experiments. Feed intake was recorded daily and calves were weighed every $14 \mathrm{~d}$. Feeds were sampled weekly to analyze DM and nutrient intake. Mixed diets in experiment 2 were analyzed for $\mathrm{CP}$ in wk 4 and 6 to assess feed sorting (calculated as actual CP intake as a percentage of predicted intake). In experiment 1 , calves offered SB $+\mathrm{S}$ in wk 1 to 6 consumed more high-protein pellet than calves offered CM $+\mathrm{S}[73$ vs. $42 \%$ of DM intake (DMI)] and, consequently, more CP (168 vs. $117 \mathrm{~g} / \mathrm{d}$ ). Solid feed DMI and average daily gain were similar between treatments. When offered a single diet in wk 7 to 8 , calves offered starter containing soybean meal increased intake to a greater extent than calves offered the starter containing canola meal. In experiment 2, calves preferred the SB mix to CM mix (preference ratio: 0.7). Calves consumed more CP than predicted from SB mix in wk 4 and $6(108 \pm$ $2.0 \%$ ), indicating that they were sorting in favor of SB. In contrast, calves consumed less $\mathrm{CP}$ than predicted
\end{abstract}

Received December 10, 2013.

Accepted March 8, 2014.

${ }^{1}$ Corresponding author: alex.bach@irta.es from CM mix in wk $4(81.48 \pm 4.1 \%)$, indicating that they were sorting against CM. When assigned to choice treatments in wk 7 to 8 of experiment 2, calves offered $\mathrm{SB}+\mathrm{S}$ consumed more protein pellet than calves offered CM + S (81 vs. 31\% DMI) and consumed more CP (378 vs. $196 \mathrm{~g} / \mathrm{d}$ ). Average daily gain was greater for calves offered SB + S but DMI was similar. Overall, these results suggest that dietary selection was influenced by innate feed preferences, and milk-fed calves may not be sensitive to protein imbalances in their diet. Key words: dairy calf, feed intake, feed sorting, palatability, protein

\section{INTRODUCTION}

Performance of dairy calves early in life depends on adequate solid feed intake, which is necessary for rumen development (Warner et al., 1956; Baldwin et al., 2004) and allows calves to maintain growth through the transition of weaning (Jasper and Weary, 2002; Terré et al., 2007). Due to the importance of encouraging solid feed intake, palatability of feed is considered to be crucial in formulating rations for dairy calves (Drackley, 2008). When provided with choices of different feed types in short-term preference tests, calves exhibit different relative preferences for a variety of feed types (Montoro et al., 2012; Miller-Cushon et al., 2014), indicating that perception of palatability affects short-term intake. It is, however, less clear to what extent palatability of provided feed types may affect longer-term dietary choice and nutrient intake of dairy calves.

Although evidence indicates that calves and adult cattle possess innate preferences for flavors and feed types that may be considered most palatable (Nombekela et al., 1994; Montoro et al., 2012), some studies indicate that ruminants are able to associate sensory properties of feed with positive or negative postingestive feedback and select nutritionally balanced diets from a variety of foods (Provenza and Balph, 1987; Forbes, 2007; Bach et al., 2012). For example, lambs offered a low protein food and a high protein food were able to choose a mixture that provided optimal amounts of protein for growth (Kyriazakis and Oldham, 1993). This suggests that longer-term dietary choices of dairy calves may be 
affected by nutrient composition of offered feed types in addition to innate preferences for sensory properties of feed.

The objective of the present study was to evaluate the effect of protein source palatability, as previously determined in short-term preference tests, on intake and dietary selection of calves over an extended period of time. Calves have been found to prefer soybean meal to a variety of other protein sources, including canola meal, in short-term preference tests (Montoro and Bach, 2012; Miller-Cushon et al., 2014), suggesting that soybean meal is perceived as highly palatable. In a first experiment, we evaluated the effect of protein source on nutrient intake and performance of calves over the first $6 \mathrm{wk}$ of life. Calves were offered a choice of a base starter pellet and either a soybean meal or canola meal high-protein pellet. In the second experiment, we evaluated preference and feed sorting of calves offered a choice of 2 pelleted mixed diets, 1 containing the soybean pellet and 1 containing the canola meal pellet. Finally, we assessed the effect of protein source on intake and performance when dietary choice was restricted: in the first experiment, ability to select preferred levels of protein from the provided protein source was restricted through provision of a single ration with a fixed protein level. In the second experiment, ability to select the preferred protein source was restricted through provision of a single protein source.

The overall hypothesis of this study was that if dietary selection is driven by nutrient requirements protein intake over time would be similar regardless of protein source. Alternatively, if dietary selection is driven by sensory properties of feed choices, calves may consume less protein when provided a less preferred protein source or, if provided a choice, select against the less preferred source. In addition, it was hypothesized that, if palatability affects diet selection to a greater extent than protein requirements, total intake and growth may be negatively affected when only a less preferred protein source is provided.

\section{MATERIALS AND METHODS}

\section{Animals and Housing}

A total of 62 Holstein bull calves were used in 2 experiments, run concurrently in January to March, 2013. The first experiment was conducted with 40 calves $(11.4 \pm 4.3 \mathrm{~d}$ of age and $44.6 \pm 4.5 \mathrm{~kg}$ of BW; mean \pm SD) and the second experiment was conducted with 22 calves $(9.9 \pm 4.6 \mathrm{~d}$ of age and $43.2 \pm 4.4 \mathrm{~kg}$ of BW). Calves were acquired on loan from a commercial rearing operation (Agricola Mas Jonquer, Girona, Spain) and raised in the facilities of Institut de Recerca i Tec- nologia Agroalimentàries (IRTA; Barcelona, Spain) in Torre Marimon (Caldes de Montbui, Spain) managed under the guidelines and approval of the Animal Care Committee of IRTA. At arrival, calves were given a broad-spectrum antibiotic (tulathromycin, Draxxin, Pfizer Animal Health, Madrid, Spain) as a preventive measure to reduce incidence of illness (Stanton et al., 2013). Calves were housed in individual hutches $(1.0 \times$ $1.6 \mathrm{~m}$; width $\times$ depth). The interior of each hutch was bedded twice weekly with wood shavings. All calves had access to 3 buckets (capacity of $6 \mathrm{~L}$ ) located at the front of the hutches, suspended in a horizontal surface, and spaced $10 \mathrm{~cm}$ apart. Water was provided ad libitum in 1 bucket and solid feed was provided in the remaining 2 buckets according to treatment. Fresh feed was delivered daily at $1000 \mathrm{~h}$.

Milk replacer (25\% CP and 19.2\% fat, Sprayfo Excellent 60 , Sloten BV, Deventer, Holland) was offered in teat feeding bottles twice daily at 0800 and $1700 \mathrm{~h}$. Calves were allowed a 6 -d adaptation period to the milk replacer; the feeding level and DM concentration of the offered milk replacer were incrementally increased from $4 \mathrm{~L} / \mathrm{d}$ at $10 \% \mathrm{DM}$ on $\mathrm{d} 1$ to $6 \mathrm{~L} / \mathrm{d}$ at $12.5 \% \mathrm{DM}$ on $\mathrm{d}$ 7. After adaptation, all calves received $6 \mathrm{~L} / \mathrm{d}$ at $12.5 \%$ DM $(750 \mathrm{~g} / \mathrm{d}$ of DM) for the remaining $7 \mathrm{wk}$ of both experiments. Calves usually finished their entire milk replacer allotment and, thus, intake was held constant across treatments (after adaptation week, $0.749 \mathrm{~kg} / \mathrm{d}$ of $\mathrm{DM}, \mathrm{SE}=0.0013, P=0.9)$.

\section{Experiment 1: Effect of Protein Source on Intake and Performance}

In experiment 1 , calves were offered a choice of 2 pelleted feeds in 2 separate buckets: a base starter pellet (S), formulated to be low in protein (Table 1), and a protein supplement pellet. Calves were randomly assigned to receive 1 of 2 types of protein pellets: (1) soybean pellet $(\mathbf{S B}+\mathbf{S} ; \mathrm{n}=20$ calves), or (2) canola pellet $(\mathbf{C M}+\mathbf{S} ; \mathrm{n}=20$ calves $)$. Thus, calves in the $\mathrm{SB}+\mathrm{S}$ treatment had access to a bucket of water, a bucket containing $\mathrm{S}$, and a third bucket containing $\mathrm{SB}$, whereas calves in the $\mathrm{CM}+\mathrm{S}$ treatment had access to a bucket of water, a bucket containing $\mathrm{S}$, and a third bucket containing CM. Both protein pellets were formulated to have similar nutrient content, particularly with respect to $\mathrm{CP}$ content (Table 1). To prevent any effect of particle size on preference for the protein source and to provide a physical basis for the calves to differentiate nutrient content between base starter and protein pellet, both protein pellets were $5 \mathrm{~mm}$ in diameter, whereas the base starter pellets were $3 \mathrm{~mm}$ in diameter. Calves were offered the 2 feed types ad libitum for $6 \mathrm{wk}$. The position of each feed type (right or 
MILLER-CUSHON ET AL.

Table 1. Ingredient and nutrient composition of feed types and mixed diets $(\text { mean } \pm \mathrm{SD})^{1}$

\begin{tabular}{|c|c|c|c|c|c|}
\hline Composition & S pellet & CM pellet & SB pellet & CM starter ${ }^{2}$ & SB starter ${ }^{2}$ \\
\hline \multicolumn{6}{|l|}{ Ingredient, $\%$} \\
\hline Barley & 28.7 & - & - & 20.0 & 20.0 \\
\hline Corn & 51.6 & - & - & 36.0 & 36.0 \\
\hline Wheat bran & 15.6 & - & - & 10.9 & 10.9 \\
\hline Mineral premix ${ }^{3}$ & 3.8 & - & - & 2.7 & 2.7 \\
\hline Canola meal & - & 100.0 & - & 30.3 & - \\
\hline Soybean meal & - & - & 62.3 & - & 18.9 \\
\hline Soybean hulls & - & - & 37.7 & - & 11.4 \\
\hline \multicolumn{6}{|l|}{ Nutrient, ${ }^{4} \%$} \\
\hline DM & $88.8 \pm 0.01$ & $89.6 \pm 0.07$ & $88.3 \pm 0.14$ & $89.3 \pm 0.36$ & $88.9 \pm 0.62$ \\
\hline $\mathrm{CP}$ & $11.8 \pm 0.18$ & $40.0 \pm 2.64$ & $37.9 \pm 2.27$ & $18.4 \pm 0.54$ & $18.0 \pm 0.54$ \\
\hline NDF & $20.3 \pm 2.38$ & $23.4 \pm 0.58$ & $30.4 \pm 0.79$ & $21.1 \pm 1.4$ & $22.0 \pm 1.6$ \\
\hline Ether extract & $3.84 \pm 0.25$ & $2.65 \pm 0.21$ & $2.36 \pm 0.12$ & $3.79 \pm 0.22$ & $2.58 \pm 0.12$ \\
\hline
\end{tabular}

${ }^{1} \mathrm{~S}$ pellet $=$ starter pellet; CM pellet $=$ canola meal pellet; SB pellet $=$ soybean meal pellet. CM pellet and $\mathrm{SB}$ pellet were $5 \mathrm{~mm}$ in diameter, and base starter pellet was $3 \mathrm{~mm}$ in diameter.

${ }^{2} \mathrm{CM}$ starter nutrient composition was equivalent to $70 \% \mathrm{~S}$ pellet and $30 \%$ canola pellet; SB starter nutrient composition was equivalent to $70 \% \mathrm{~S}$ pellet and $30 \% \mathrm{SB}$ pellet.

${ }^{3}$ Mineral premix contained (on as-is basis): $41.5 \%$ calcium carbonate, $30.2 \%$ salt, $26.2 \%$ dicalcium phosphate, $1.84 \%$ magnesium oxide, and $0.2 \%$ micromineral premix (containing: vitamin A 2,007,000 IU $/ \mathrm{kg}$; vitamin $\mathrm{D}_{3}$ 433,000 IU $/ \mathrm{kg}$; vitamin $\mathrm{E}_{3} 685 \mathrm{mg} / \mathrm{kg}$; vitamin $\mathrm{B}_{1} 52 \mathrm{mg} / \mathrm{kg}$; vitamin $\mathrm{B}_{2} 197 \mathrm{mg} / \mathrm{kg}$; vitamin $\mathrm{B}_{6} 98 \mathrm{mg} / \mathrm{kg}$; vitamin $\mathrm{B}_{12} 0.76 \mathrm{mg} / \mathrm{kg}$; vitamin $\mathrm{K}_{3} 52 \mathrm{mg} / \mathrm{kg}$; nicotinic acid $656 \mathrm{mg} / \mathrm{kg}$; pantothenic acid $394 \mathrm{mg} / \mathrm{kg} ; \mathrm{Mn}$ $5,877 \mathrm{mg} / \mathrm{kg}$; Fe 7,093 mg/kg; Cu 2,026 mg/kg; Co 46 mg/kg; Zn 8,112 mg/kg; I 304 mg $/ \mathrm{kg}$; Se 46 mg/kg).

${ }^{4}$ Values obtained from chemical analysis of feed types $(\mathrm{n}=3$ samples analyzed per feed type).

left) was randomly assigned to each calf to account for potential side preferences but held constant from day to day to improve their ability to learn about the offered feed types (Howery et al., 2000). Water was placed to the right in each pen, below the position where the milk bottle was provided.

In wk 7 and 8 , calves were offered a single starter pellet (3 $\mathrm{mm}$ in diameter) formulated with the protein source to which they had previously been exposed to assess how intake was affected when the ability to select a preferred level of protein was restricted. Calves previously offered $\mathrm{SB}+\mathrm{S}$ were offered a single starter pellet containing soybean (SB starter; Table 1) and calves previously offered $\mathrm{CM}+\mathrm{S}$ were offered a single starter pellet containing canola meal (CM starter; Table 1). Nutrient composition of both starter rations was simi- lar (Table 1), such that they differed only in the protein source. Application of treatment diets during different time periods is shown in Table 2 .

\section{Experiment 2: Diet Selection and Feed Sorting of Calves Offered Mixed Rations Differing in Protein Source}

In experiment 2, all calves were offered a choice of 2 feeds: a mixed ration composed of $70 \%$ base starter pellet and 30\% canola pellet (CM-MIX) and a mixed ration composed of $70 \%$ pelleted base starter pellet and $30 \%$ soybean pellet (SB-MIX). Therefore, all calves had access to a bucket of water, a bucket containing CM-MIX, and a third bucket containing SB-MIX. The same pelleted feeds were used as in experiment 1, with

Table 2. Assignment of treatment diets in experiments 1 and $2^{1}$

\begin{tabular}{|c|c|c|c|c|c|}
\hline \multirow[b]{3}{*}{ Treatment diet } & \multirow[b]{3}{*}{$\mathrm{n}$} & \multicolumn{4}{|c|}{ Time period } \\
\hline & & \multicolumn{2}{|c|}{ Wk 1-6 } & \multicolumn{2}{|c|}{ Wk 7-8 } \\
\hline & & Feed choice 1 & Feed choice 2 & Feed choice 1 & Feed choice 2 \\
\hline \multirow[t]{2}{*}{ Experiment 1} & 20 & SB pellet & S pellet & SB starter & - \\
\hline & 20 & CM pellet & $\mathrm{S}$ pellet & CM starter & - \\
\hline \multirow{2}{*}{ Experiment 2} & 11 & SB-MIX & CM-MIX & SB pellet & $S$ pellet \\
\hline & 11 & SB-MIX & CM-MIX & CM pellet & $\mathrm{S}$ pellet \\
\hline
\end{tabular}


nutrient composition described in Table 1. For the first $7 \mathrm{~d}$, calves were offered individual feed types in separate buckets to provide an opportunity to learn about feed types before receiving them as a mixture. On each of these $7 \mathrm{~d}$, calves received the base starter pellet in one bucket and a protein pellet in the second bucket. Calves were offered the soybean pellet and canola pellet on alternating days, with the order of exposure randomized across calves. Following the week of exposure to individual feed types, calves received a choice of both mixed diets ad libitum for $5 \mathrm{wk}$. The position of the mixtures (right or left) was randomly assigned to each calf to account for potential side preferences, but held constant day to day throughout the study.

In wk 7 and 8, calves were offered a choice of the base starter pellet and only one protein source, to assess how intake and protein pellet selection were affected when the choice of protein source was removed, and the protein source available was restricted to either the "palatable" source or the "less palatable" source. Calves were randomly assigned to receive a choice of the base starter pellet, in one bucket, and, in the second bucket, either (1) the CM pellet ( $\mathrm{CM}+\mathrm{S} ; \mathrm{n}=11$ calves), or (2) the $\mathrm{SB}$ pellet ( $\mathrm{SB}+\mathrm{S} ; \mathrm{n}=11$ calves). The bucket containing the protein pellet was placed on the side on which the mixture containing that protein pellet had previously been placed, whereas the base starter pellet was placed on the alternate side. Application of treatment diets during different time periods is described in Table 2.

\section{Performance Measurements}

In both experiments, daily intake of all offered feed types was determined by weighing the quantity of feed offered and feed refused. Calves were weighed every 14 $\mathrm{d}$, beginning on $\mathrm{d} 1$.

\section{Feed Analysis}

To determine DM and nutrient content of all offered feed types in both experiments, weekly samples of all feed types offered in each week were taken. In wk 1 to 6 , samples were taken of the base starter pellet, CM pellet, and SB pellet. In wk 7 and 8, samples were taken of the base starter pellet, CM pellet, SB pellet, CM starter, and SB starter. Samples were pooled for nutrient analysis within feed type across 3 time periods (wk 1-3, wk 4-6, and wk 7-8). Samples were sent to Laboratorio de Mouriscade (Pontevedra, Spain) for analysis of $\mathrm{DM}\left(24 \mathrm{~h}\right.$ at $\left.103^{\circ} \mathrm{C}\right)$, NDF with heat-stable amylase and sodium sulfite (Van Soest et al., 1991), ether extract (AOAC International, 2000; 920.39), and N content (Van Soest et al., 1991; AOAC International,
2000). Orts samples were taken from each calf and feed type in each week and pooled by treatment and time period (wk 1-3, wk 4-6, wk 7-8) for analyses of DM content to assess DMI of each feed type.

In addition, feed sorting within the SB mix and CM mix diets was assessed in experiment 2. Selection for or against the starter pellet or the protein pellet was evaluated through nutrient analysis for $\mathrm{CP}$ content in wk 4 and 6: fresh samples were taken of the SB mix and CM mix on $\mathrm{d} 1$ to 4 of both weeks and orts samples were taken of both pellet mixtures from all calves on $\mathrm{d} 1$ to 4 of both weeks. Fresh samples were pooled by week and mixture and orts samples were pooled by week, mixture, and calf. These samples were sent to Laboratorio de Mouriscade for analysis of DM and CP content.

\section{Calculations and Statistical Analyses}

Experiment 1. Preference for the 2 offered protein sources was assessed in wk 1 to 6 through calculation of a preference ratio: [DMI of protein pellet/(DMI of protein pellet + DMI of base starter pellet)]. All data were summarized for each calf in each week. Average daily gain was calculated as the difference between consecutive BW measurements divided by 14 .

To satisfy assumptions of normality evaluated using box plots and tests of normality (PROC UNIVARIATE; SAS Institute, 2008), starter DMI data were log-transformed and protein pellet DMI data were square root-transformed to correct for varying degrees of positive skewness. To examine the effect of treatment in wk 1 to 6 of experiment 1, all data (BW, ADG, starter DMI, protein pellet DMI, total DMI, CP intake, and preference ratio) were analyzed using the MIXED procedure of SAS (SAS Institute, 2008), treating week as a repeated measure (except for weight data, where BW was measured every $14 \mathrm{~d}$, and thus data from 14-d intervals were treated as the repeated measure). The model included initial BW and age as covariates, the fixed effects of week, treatment, and week $\times$ treatment interaction, and the random effect of calf within treatment. The autoregressive model was selected as the variance-covariance matrix structure for all data on the basis of best fit according to Schwarz's Bayesian information criterion. Additionally, preference ratios were summarized by week and calf and tested by week within treatment for a difference from 0.5 (lack of preference) using $t$-tests within the MIXED procedure of SAS (SAS Institute, 2008). When calves were offered a single ration in wk $7-8$, the effect of treatment on ADG and DMI was analyzed as in wk 1-6.

Experiment 2. Preference for the mixed diets in wk 2 to 6 was assessed through calculation of a preference ratio: [DMI of SB mix/(DMI of SB mix + DMI of CM 
mix)]. Selection for or against the protein pellet within the SB mix and CM mix was calculated as actual intake of $\mathrm{CP}$ expressed as a percentage of the predicted intake (Leonardi and Armentano, 2003). The actual CP intake for both mixtures was calculated as the difference between the amount of $\mathrm{CP}$ in the offered feed and that in the refused feed. The predicted intake of $\mathrm{CP}$ was calculated as the product of total DMI of that feed mixture multiplied by the DM percentage of CP in the fed ration. Thus, values equal to $100 \%$ indicate no selection for or against the protein pellet, values $<100 \%$ indicate selective refusals of the protein pellet (sorting against), and values $>100 \%$ indicate preferential consumption of the protein pellet (sorting for).

To test whether sorting of the pellet mixtures occurred, CP intake, as a percentage of predicted intake, was summarized by calf, diet (SB mix and CM mix), and week (wk 4 and 6 ). Sorting values were tested by week and diet for a difference from 100 using $t$-tests within the MIXED procedure of SAS (SAS Institute, 2008). To assess preference between the 2 mixed diets, preference ratios were summarized by week and calf and tested in wk 4 and 6 for a difference from 0.5 (lack of preference) using $t$-tests within the MIXED procedure of SAS (SAS Institute, 2008). In addition, the difference between mixed diets in total $\mathrm{CP}$ intake and $\mathrm{CP}$ intake as a percentage of DMI was analyzed in wk 4 and 6 as an indication of the extent to which dietary selection and sorting affected nutrient intake from each mixture. Because data sets obtained from the same calf could not be assumed to be independent, these data were analyzed within calf by week using dependent group $t$-tests (SAS Institute, 2008).

In wk 7 to 8 of experiment 2, when calves were assigned to separate treatments $(\mathrm{SB}+\mathrm{S}$ or $\mathrm{CM}+\mathrm{S})$, intake data [DMI, CP intake, and preference ratio (DMI of protein pellet/total DMI)] were summarized by week and analyzed using the MIXED procedure of SAS (SAS Institute, 2008), treating week as a repeated measure. The model included initial BW as a covariate, the fixed effects of week, treatment, and week $\times$ treatment interaction, and the random effect of calf within treatment. The autoregressive model was selected as the variance-covariance matrix structure for all data on the basis of best fit according to Schwarz's Bayesian information criterion. Growth data (ADG and final BW) were also analyzed using the MIXED procedure of SAS (SAS Institute, 2008). The model included initial BW as a covariate, the fixed effect of treatment, and the random effect of calf within treatment.

Results are reported as least squares means, corresponding to nontransformed data. Significance was declared at $P \leq 0.05$, and trends reported if $0.05<P$ $\leq 0.10$.

\section{RESULTS}

\section{Experiment 1}

Protein source affected dietary selection in experiment 1. Calves offered SB $+\mathrm{S}$ preferred the $\mathrm{SB}$ protein pellet to the $\mathrm{S}$ pellet, whereas calves offered $\mathrm{CM}+$ $\mathrm{S}$ showed no preference for either type of feed (Table 3 ). Protein pellet intake was subject to a treatment $x$ week interaction as well as a treatment effect: calves offered SB $+\mathrm{S}$ consumed more protein pellet than calves offered CM + S (Table 3) and increased their intake of protein pellet over time to a greater extent (Figure 1). Base starter pellet intake was also subject to a treatment $\times$ week interaction: calves offered $\mathrm{CM}$ $+\mathrm{S}$ consumed more $\mathrm{S}$ starter and increased intake of $\mathrm{S}$ pellet to a greater extent over time (Figure 1) than calves offered SB + S (Table 3). Total DMI was similar between treatments (Table 3); however, CP intake was subject to a treatment $\times$ week interaction and a treatment effect (Table 3), corresponding to greater protein pellet intake. Despite differences in $\mathrm{CP}$ intake, ADG was similar throughout wk 1 to 6 of the study (0.67 $\mathrm{kg} / \mathrm{d}, \mathrm{SE}=0.04 \mathrm{~kg} / \mathrm{d} ; P=0.8)$ and $\mathrm{BW}$ was similar at the end of wk $6(72.7 \mathrm{~kg}, \mathrm{SE}=2.0 \mathrm{~kg} ; P=0.8)$.

In wk 7 to 8 , when both treatments were provided a single starter pellet containing the protein source to which they had previously been exposed, we detected a treatment $\times$ week interaction for total DMI and CP intake (Table 3). Calves offered the soybean-based starter (previously offered SB $+\mathrm{S}$ ) increased intake (both DM and $\mathrm{CP}$ ) during these 2 wk to a greater extent than calves offered the canola-based starter. Calves maintained similar ADG in wk 7 to $8(0.927 \mathrm{~kg} / \mathrm{d}, \mathrm{SE}=$ $0.074 \mathrm{~kg} / \mathrm{d} ; P=0.75)$ and BW was similar at the end of wk $8(85.7 \mathrm{~kg}, \mathrm{SE}=2.5 ; P=0.8)$.

\section{Experiment 2}

During the week of exposure to individual feeds (wk 1), in which calves were offered the S pellet daily and $\mathrm{CM}$ or SB pellet on alternating days, calves consumed similar amounts of $\mathrm{S}$ regardless of the type of protein pellet offered $(44.9 \mathrm{~g} / \mathrm{d}, \mathrm{SE}=9.9 \mathrm{~g} / \mathrm{d} ; P=0.9)$ but consumed more protein pellet on days when SB pellet was offered compared with days when $\mathrm{CM}$ pellet was offered (112.6 vs. $57.8 \mathrm{~g} / \mathrm{d}, \mathrm{SE}=16.4 \mathrm{~g} / \mathrm{d} ; P=0.04)$. The amount of protein pellet consumed increased $(P=$ 0.04) over time during the week of exposure, whereas the amount of $\mathrm{S}$ pellet consumed was similar over time $(P=0.58)$.

Calves preferred the SB mix to the CM mix in both wk 4 (preference ratio: $0.65 \pm 0.03 ; P<0.001$ ) and wk $6(0.70 \pm 0.02 ; P<0.001)$. In wk 4 , calves consumed 


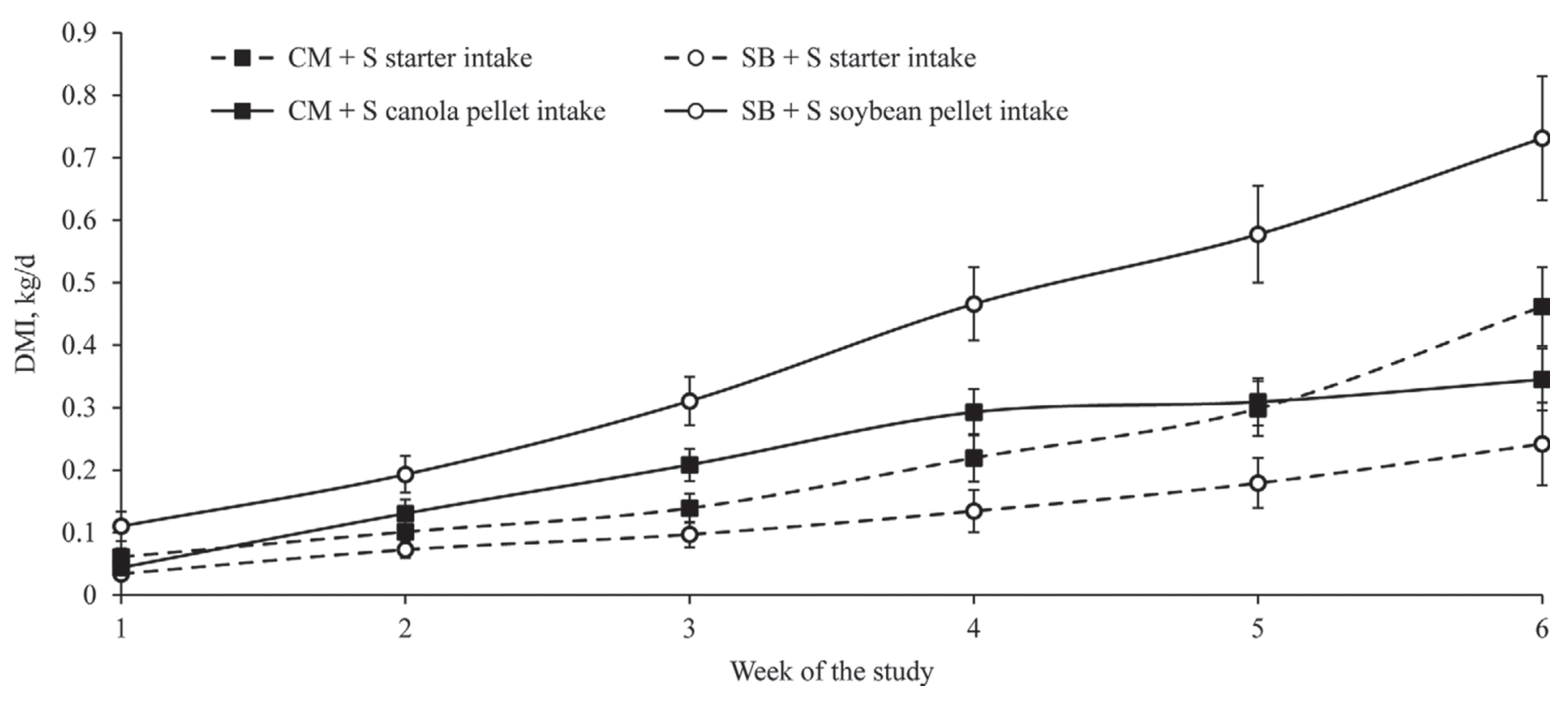

Figure 1. Intake over time of calves in experiment 1 offered a choice of a base starter pellet $(\mathrm{S})$ and a high-protein pellet containing either canola meal $(\mathrm{CM}+\mathrm{S})$ or soybean meal $(\mathrm{SB}+\mathrm{S})$.

$148.9 \pm 24.8 \mathrm{~g} / \mathrm{d}$ of $\mathrm{CM}$ mix and $333.7 \pm 48.6 \mathrm{~g} / \mathrm{d}$ of SB mix. In wk 6 , calves consumed $220.4 \pm 27.2 \mathrm{~g} / \mathrm{d}$ of $\mathrm{CM}$ mix and $562.7 \pm 56.3 \mathrm{~g} / \mathrm{d}$ of SB mix. Crude protein intake was less than predicted for calves offered CM mix and greater than predicted for calves offered SB mix in wk 4 (Table 4), clearly indicating that calves were selecting against the $\mathrm{CM}$ pellet in the $\mathrm{CM}$ mix and selecting in favor of the SB pellet in the SB mix. Calves continued to consume more $\mathrm{CP}$ than predicted for the SB mix in wk 6 (Table 4) but did not select within the

Table 3. Solid feed and nutrient intake and dietary preferences of calves in experiment 1 provided a choice of a base pelleted starter $(S)$ and a protein pellet containing either canola meal $(C M ; n=20)$ or soybean meal $(\mathrm{SB} ; \mathrm{n}=20)$

\begin{tabular}{|c|c|c|c|c|c|c|}
\hline \multirow[b]{2}{*}{ Item } & \multicolumn{2}{|c|}{ Treatment $(\mathrm{T})^{1}$} & \multirow[b]{2}{*}{$\mathrm{SE}$} & \multicolumn{3}{|c|}{$P$-value ${ }^{2}$} \\
\hline & $\mathrm{CM}+\mathrm{S}$ & $\mathrm{SB}+\mathrm{S}$ & & $\mathrm{T}$ & $\mathrm{W}$ & $\mathrm{T} \times \mathrm{W}$ \\
\hline \multicolumn{7}{|l|}{ Week 1 to 6} \\
\hline Base starter pellet intake, $\mathrm{g} / \mathrm{d}$ & 213.1 & 125.0 & 36.0 & 0.002 & $<0.001$ & $<0.001$ \\
\hline Protein pellet intake, $\mathrm{g} / \mathrm{d}$ & 221.3 & 394.5 & 44.6 & 0.004 & $<0.001$ & 0.04 \\
\hline Total solid feed intake, $\mathrm{g} / \mathrm{d}$ & 433.5 & 518.9 & 54.29 & 0.19 & $<0.001$ & 0.44 \\
\hline Preference ratio $^{3}$ & 0.42 & $0.73^{*}$ & 0.040 & $<0.001$ & 0.01 & 0.55 \\
\hline CP intake from feed, $\mathrm{g} / \mathrm{d}$ & 117.0 & 168.4 & 13.5 & 0.03 & $<0.001$ & 0.001 \\
\hline CP intake, $\%$ of feed DMI & 27.0 & 30.8 & 1.20 & 0.02 & 0.006 & 0.51 \\
\hline Total CP intake, $\mathrm{g} / \mathrm{d}^{4}$ & 305.8 & 356.8 & 14.5 & 0.02 & $<0.001$ & 0.004 \\
\hline $\mathrm{CP}$ intake, $\%$ of total $\mathrm{DMI}^{4}$ & 25.8 & 27.3 & 0.04 & 0.02 & $<0.001$ & 0.006 \\
\hline \multicolumn{7}{|l|}{ Week 7 to $8^{5}$} \\
\hline DMI from feed, $\mathrm{g} / \mathrm{d}$ & $1,017.8$ & $1,282.4$ & 98.8 & 0.09 & $<0.001$ & 0.02 \\
\hline $\mathrm{CP}$ intake from feed, $\mathrm{g} / \mathrm{d}$ & 186.3 & 228.3 & 17.7 & 0.06 & $<0.001$ & 0.03 \\
\hline
\end{tabular}

${ }^{1}$ Treatment (T): calves offered choice of starter pellet and either (1) canola meal pellet (CM $\left.+\mathrm{S}\right)$, or $(2)$ soybean pellet $(\mathrm{SB}+\mathrm{S})$ in week $(\mathrm{W}) 1$ to 6 of experiment 1.

${ }^{2} \mathrm{~T}=$ effect of treatment (protein source); $\mathrm{W}=$ effect of week; $\mathrm{T} \times \mathrm{W}=$ interaction between treatment and week.

${ }^{3}$ Preference ratio calculated as DMI of protein pellet (CM or SB)/(DMI of protein pellet + DMI of base starter).

${ }^{4}$ Includes milk replacer intake $(750 \mathrm{~g} / \mathrm{d}$ containing $25 \% \mathrm{CP})$.

${ }^{5}$ In wk 7 to 8 , calves previously offered $\mathrm{CM}+\mathrm{S}$ were provided a single pelleted starter containing canola meal as the protein source (CM starter; Table 1 ) and calves previously offered SB + S were provided a single pelleted starter containing soybean meal as the protein source (SB starter, Table 1).

${ }^{*} P \leq 0.01$ : difference in preference ratio from 0.5 . 
Table 4. Feed sorting, dietary preference, and nutrient intakes from solid feed of calves $(\mathrm{n}=22)$ in experiment 2 (wk 1-6) offered a choice of 2 mixed pelleted diets containing a base starter pellet and either canola meal pellet (CM mix) or soybean pellet (SB mix $)^{1}$

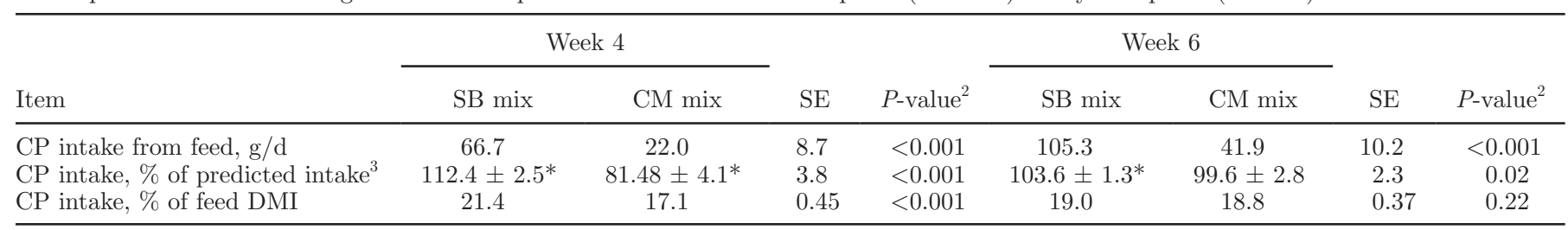

${ }^{1}$ Mixed diets contained $70 \%$ starter pellet and $30 \%$ protein pellet (SB or CM).

${ }^{2}$ Difference in measured variables between offered diets according to dependent group $t$-tests.

${ }^{3}$ Calculated as $100 \times$ (actual CP intake/predicted CP intake). Values equal to $100 \%$ indicate no sorting, $<100 \%$ indicate selective refusals of protein pellet (sorting against), and $>100 \%$ indicate preferential consumption of protein pellet (sorting for). Data are averaged over d 1 to 4 in each week.

${ }^{*} P<0.01$ : difference in CP intake (\% of predicted intake) from $100 \%$.

$\mathrm{CM}$ mix in wk 6. Calves consumed more total CP from the SB mix than the CM mix in both weeks (Table 4). Crude protein intake, as a percentage of DMI, was also greater for the SB mix (Table 4). Overall, CP intake as a percentage of DMI was $18.3 \pm 0.47 \%$ (mean $\pm \mathrm{SE}$ ) in wk 4 and $18.7 \pm 0.22 \%$ in wk 6 . During wk 1 to 6 , ADG was $0.66 \pm 0.4 \mathrm{~kg} / \mathrm{d}$, and $\mathrm{BW}$ at the end of wk 6 was $71.1 \pm 2.2 \mathrm{~kg}$ across all calves.

After assignment to choice treatments in wk 7 and 8 , calves offered $\mathrm{CM}+\mathrm{S}$ preferred the $\mathrm{S}$ pellet to the $\mathrm{CM}$ pellet in wk 8 and tended to prefer the $\mathrm{S}$ pellet in wk 7 . Calves offered SB $+\mathrm{S}$ preferred the SB pellet in both weeks (Table 5). Preference ratio for the protein pellet was subject to a treatment $\times$ week interaction, with calves offered $\mathrm{CM}+\mathrm{S}$ decreasing preference for the protein pellet relative to calves offered $\mathrm{SB}+\mathrm{S}$ (Table $5)$. Correspondingly, protein pellet intake and $S$ pellet intake were subject to treatment $\times$ week interactions and overall treatment effects, with calves offered CM $+\mathrm{S}$ consuming less protein pellet and more $\mathrm{S}$ pellet, and decreasing protein pellet intake and increasing $\mathrm{S}$ pellet intake over time relative to calves offered $\mathrm{SB}+\mathrm{S}$ (Table 5). Total DMI was similar between treatments; however, CP intake was subject to a treatment $\times$ week interaction and treatment effect, corresponding to a difference in intake of the protein pellet (Table 5). During wk 7 to 8, ADG was greater for calves offered SB $+\mathrm{S}$ than for those offered $\mathrm{CM}+\mathrm{S}(1.12$ vs. $0.87 \mathrm{~kg} / \mathrm{d}$, $\mathrm{SE}=0.055 ; P=0.006)$. Final BW was similar between treatments $(85.0 \mathrm{~kg}, \mathrm{SE}=2.06 ; P=0.85)$.

\section{DISCUSSION}

Intake of protein was affected by protein source in the first experiment, with calves consuming more protein pellet when offered the soybean meal pellet compared with the canola meal pellet. We expected that calves offered the soybean pellet would exhibit an initially greater preference for the protein pellet than calves offered the canola meal pellet, as it has been established

Table 5. Dietary selection and intake of calves $(\mathrm{n}=22)$ in experiment 2 (wk 7 and 8 ) after transition to 1 of 2 choice diets: base starter pellet and canola meal pellet $(\mathrm{CM}+\mathrm{S})$ or base starter pellet and soybean pellet $(\mathrm{SB}+\mathrm{S})^{1}$

\begin{tabular}{|c|c|c|c|c|c|c|c|c|}
\hline \multirow[b]{2}{*}{ Item } & \multicolumn{2}{|c|}{$\mathrm{CM}+\mathrm{S}$} & \multicolumn{2}{|c|}{$\mathrm{SB}+\mathrm{S}$} & \multirow[b]{2}{*}{$\mathrm{SE}$} & \multicolumn{3}{|c|}{$P$-value ${ }^{2}$} \\
\hline & Week 7 & Week 8 & Week 7 & Week 8 & & $\mathrm{~T}$ & $\mathrm{~W}$ & $\mathrm{~W} \times \mathrm{T}$ \\
\hline Starter pellet intake, $\mathrm{g} / \mathrm{d}$ & 587.0 & 845.6 & 220.56 & 276.9 & 63.9 & $<0.001$ & $<0.001$ & 0.002 \\
\hline Protein pellet intake, $\mathrm{g} / \mathrm{d}$ & 344.9 & 275.1 & 867.3 & $1,060.3$ & 78.4 & $<0.001$ & 0.06 & $<0.001$ \\
\hline Preference ratio ${ }^{3}$ & $0.38 \pm 0.06 \dagger$ & $0.23 \pm 0.05^{*}$ & $0.81 \pm 0.03^{*}$ & $0.81 \pm 0.04^{*}$ & 0.045 & $<0.001$ & 0.008 & 0.02 \\
\hline $\mathrm{CP}$ intake from feed, $\mathrm{g} / \mathrm{d}$ & 198.5 & 192.9 & 337.89 & 417.9 & 31.0 & 0.0003 & 0.004 & 0.002 \\
\hline $\begin{array}{l}\text { CP intake, }{ }^{4} \% \text { of total } \\
\text { DMI }\end{array}$ & 23.1 & 20.3 & 29.1 & 29.4 & 0.008 & $<0.001$ & 0.01 & 0.004 \\
\hline
\end{tabular}

${ }^{1}$ Data are summarized by week and calf $(\mathrm{n}=11$ on $\mathrm{CM}+\mathrm{S}$ treatment, and $\mathrm{n}=11$ on $\mathrm{SB}+\mathrm{S}$ treatment).

${ }^{2} \mathrm{~T}=$ effect of treatment canola meal pellet $(\mathrm{CM}+\mathrm{S})$ or soybean pellet $(\mathrm{SB}+\mathrm{S}) ; \mathrm{W}=$ effect of week; $\mathrm{W} \times \mathrm{T}=$ interaction between week and treatment.

${ }^{3}$ Preference ratio calculated as DMI of protein pellet CM or SB/(DMI of protein pellet + DMI of starter).

${ }^{4}$ Includes milk replacer intake (750 g/d containing $\left.25 \% \mathrm{CP}\right)$.

Difference in preference ratio from 0.5 expressed as $* P \leq 0.01, \dagger 0.05 \leq P<0.1$. 
that soybean meal is considered more palatable than canola meal in short-term preference tests (Montoro et al., 2012; Miller-Cushon et al., 2014). However, the difference in protein intake between treatments increased throughout the 6 wk that calves remained on treatment (Figure 1). The extent to which protein source affected selection of the protein pellet suggests that young calves may not be sensitive to dietary $\mathrm{CP}$ content and capable of balancing a diet with an optimal level of protein. Relatively few researchers to date have evaluated whether dairy calves without prior experience with solid feed are able to select a nutritionally balanced diet. Montoro et al. (2012) reported that calves offered a range of 6 feed ingredients compared with a single diet consumed excess protein without appropriately balancing energy intake.

In contrast to the present results, evidence indicates that lambs are able to detect dietary $\mathrm{CP}$ content and adjust intake accordingly (Kyriazakis and Oldham, 1993; Bach et al., 2012). Similarly, it has been shown that lambs provided a diet low in CP choose to forage at a location where a high protein food is provided ( $\mathrm{Scott}$ and Provenza, 2000). This dietary learning is thought to result from the association of feed sensory properties with negative postingestive feedback resulting from microbial production of excess amounts of nitrogen and production of high amounts of ammonia (Kertz et al., 1982; Provenza, 1995). In support of this, cattle show an aversion for foods paired with excess amounts of urea administered to the rumen (Kertz et al., 1982), and heifers have been found to develop aversions for feeds high in urea after several days of exposure (Chalupa et al., 1979). In the present study, it is possible that the quantity of protein in the diet consumed by calves, although greater than recommended levels, was not sufficiently high to trigger malaise resulting from excess ammonia production. Similarly, in a study conducted by Montoro et al. (2012), calves consuming excess protein had similar total intake, suggesting that over-consuming protein was not associated with a strong negative postingestive consequence. Likewise, calves in the present study had similar total feed intake, despite consuming diets that differed in CP content, suggesting that they were not experiencing negative postingestive feedback resulting from over-consuming protein.

Dietary learning by calves in the present study may have been impeded by several factors. Developing the associations required to select feeds based on nutrient content is challenged by the time delay between ingesting a food and experiencing the consequences of a nutrient deficiency or excess (Yearsley et al., 2006), and provision of multiple feeds simultaneously complicates association of individual feed with related postingestive consequence (Duncan and Young, 2002). Calves in the present study were consuming both a liquid diet and a solid diet, whereas studies that demonstrated the ability of lambs to balance protein intake were conducted with older animals (>60 d; Bach et al., 2012, or 90 d; Scott and Provenza, 2000) that were completely weaned. It is possible that the presence of a liquid diet voids the ability to select solid feed based on nutritive status and metabolic signals. If not capable of learning the association between postingestive feedback and sensory properties of individual feeds, calves might rely on innate preference for feed characteristics to inform diet choices.

It is interesting to note that even calves offered the canola pellet, which is considered less palatable than soybean meal (Montoro et al., 2012; Miller-Cushon et al., 2014), consumed more CP than estimated requirements dictate, suggesting that calves may be motivated to consume a minimum dietary protein level. The NRC (2001) recommendation for CP intake for calves gaining weight at 0.6 to $0.8 \mathrm{~kg} / \mathrm{d}$ and consuming both milk replacer and starter feed is approximately 220 to 260 $\mathrm{g} / \mathrm{d}$ and $21 \%$ of total DMI. In contrast, calves offered canola meal protein pellet in the present study consumed over $300 \mathrm{~g} / \mathrm{d}$ of $\mathrm{CP}$ at a rate of approximately $26 \%$ of total DMI. Similarly, Montoro et al. (2012) reported that calves offered a choice of 6 different feed ingredients selected a diet containing $29 \% \mathrm{CP}$. It is unclear why calves consistently over-consumed protein but it is interesting to note that the proportion of $\mathrm{CP}$ selected from the choice of feeds approached the CP content of milk $(\sim 26 \%)$. Nevertheless, studies exploring the effect of dietary $\mathrm{CP}$ level on performance of calves offered a milk replacer high in protein $(>26 \%$, similar to the present study) have suggested that there is little advantage to providing a starter containing greater than 18 to $20 \%$ CP (Hill et al., 2007; Stamey et al., 2012). In the present study, the similar BW and ADG between treatments despite differences in $\mathrm{CP}$ intake suggest that energy was limiting and, thus, calves offered a choice were consuming an unbalanced $\mathrm{CP}$ to energy ratio, similar to results reported by Montoro et al. (2012).

When calves in experiment 1 were offered a single pelleted diet containing either soybean meal or canola meal in wk 7 to 8 , total intake was affected by protein source. Previous results suggest that palatability has the potential to affect short-term intake and relative preference, but has little effect on longer-term intake of adult ruminants offered a single feed (Gherardi et al., 1991; Forbes, 2007). Fiems et al. (1985) replaced soybean meal with rapeseed meal in a starter ration for dairy calves (at 20\% DM) and noted little effect on total intake but a reduction in rate of intake. It is possible 
that the effect of protein source on intake may have eventually diminished in the present study, as intake was regulated over a longer period of time. However, differences in intake between calves offered different protein sources increased over the 2 wk of exposure. This suggests that sensory properties of feed may affect total intake of young calves, and that certain feeds, such as soybean meal, could be used to improve intake at time intervals when adequate intake is important, such as weaning.

In the second experiment, calves were offered a choice between feed types on 2 levels: between mixture and within mixture. Calves preferred the mixture containing soybean meal pellet to the mixture containing canola meal pellet, consistent with previous results of pairwise preference tests, which indicate that soybean meal is perceived as more palatable than canola meal (Montoro et al., 2012; Miller-Cushon et al., 2014). The preference for the mixture containing 30\% soybean meal pellet indicates that relative palatability of feed mixtures can be improved by inclusion of a preferred feed type, similar to results reported by Miller-Cushon et al. (2014). Within mixtures, calves sorted for soybean meal pellet, consistent with the preference for soybean meal pellet compared with starter feed exhibited by calves in experiment 1 , and sorted against canola meal pellet. These results indicate that calves are adept at feed sorting from a young age and are able to recognize different feed ingredients even when they are in a similar pelleted form. In previous studies, feed sorting behavior of calves has only been observed when calves are offered a diet containing forage and concentrate (Montoro et al., 2013; Miller-Cushon et al., 2013a,b) where sorting could be driven by particle size and fiber and energy requirements. In the present study, it is unlikely that sorting occurred to modify desired dietary proportion of $\mathrm{CP}$, as calves sorted against the protein source in one mixture and for it in the other. Thus, feed sorting by these calves was likely motivated solely by a preference for sensory properties of feed.

Whereas the results of experiment 1 suggest that calves are motivated to consume excess protein even when provided canola meal protein pellet, feed sorting behavior in experiment 2 did not reflect a similar motivation. Sorting against the canola meal pellet in wk 4 resulted in calves consuming only $17 \% \mathrm{CP}$ from that mixed diet, which is below the estimated CP requirements for calves (NRC, 2001). Given an apparent dislike of canola meal pellet and motivation to select against it within the mixed diet, it is perhaps surprising that calves consumed 30 to $35 \%$ of their diet from the canola meal mixture rather than avoiding it entirely. This may be explained by a motivation to sample all available feed choices and thus monitor the environ- ment (Kyriazakis and Oldham, 1993; Cooper et al., 1995). Kyriazakis and Oldham (1993) reported that lambs continued to consume small amounts of a feed high in $\mathrm{CP}$ after having met their protein requirements. Alternatively, evidence suggests that ruminants prefer diet diversity and that foraging decisions are influenced by the variety of feeds available (Scott and Provenza, 1998; Favreau-Peigné et al., 2013), suggesting that calves may have been motivated to consume amounts of both diet choices to increase sensory diversity.

When calves in experiment 2 were assigned to choice treatments at the beginning of wk 7, calves offered CM $+\mathrm{S}$ in experiment 2 consumed a diet consisting of only $40 \%$ canola meal pellet in wk 7 , decreasing to $20 \%$ in wk 8. Therefore, whereas calves offered $\mathrm{SB}+\mathrm{S}$ consumed an excess of CP (32\% of feed DMI), calves offered CM $+\mathrm{S}$ selected a diet containing less than $17 \% \mathrm{CP}$ in wk 8. In contrast to the results of experiment 1 , greater $\mathrm{CP}$ intake by calves offered $\mathrm{SB}+\mathrm{S}$ corresponded to an increase in ADG, indicating that calves offered $\mathrm{CM}+$ $\mathrm{S}$ selected a diet where protein was limiting. Similarly, Akayezu et al. (1994) reported that growth of calves was negatively affected when dietary $\mathrm{CP}$ fell below $17 \%$.

The relative preferences for soybean meal and canola meal exhibited in wk 7 to 8 of experiment 2 were more pronounced than those observed in experiment 1. Although it is difficult to directly compare these results because choice diets were offered at different time points, it is possible that differences in previous experience affected preference. Calves in experiment 2 were exposed to both soybean meal and canola meal during wh 1 to 6 , whereas calves in experiment 1 were exposed to only one protein source for the duration of the experiment. It has been established that previous experience with feed influences preference for different feeds (Nolte et al., 1990; Miller-Cushon and DeVries, 2011). In the present study, it is possible that previous experience with a choice of mixed diets containing both protein sources may have enhanced relative preference for soybean meal in experiment 2, resulting in greater avoidance of canola meal pellet when the option to choose the soybean pellet was removed.

\section{CONCLUSIONS}

Selection of dietary protein was influenced by protein source, with calves selecting a diet greater in protein when a soybean meal pellet was offered in contrast to a canola meal pellet. When provided a single diet formulated containing only soybean meal or canola meal, calves offered the starter containing soybean meal increased intake to a greater extent, indicating that palatability may affect short-term intake. Further, feed 
sorting of calves offered a choice of mixed pelleted diets was influenced by protein source rather than nutrient content. Overall, these results indicate that dietary selection during early weeks of life is influenced by innate feed preferences and that dairy calves are not capable of balancing a diet with an optimal level of protein, at least during the milk-feeding stage.

\section{ACKNOWLEDGMENTS}

We thank the staff and students at the Torre Marimon facility (Caldes de Montbui, Spain), in particular Gemma Araujo, Llorenç Castells, and Anna Domenech for their technical assistance. In addition, we thank Jordi Casino, Pep Llauger, Joan Suriñach, and Juan Vicente (all from Institut de Recerca i Tecnologia Agroalimentàries, Barcelona, Spain) for their help with calf management. Emily Miller-Cushon was supported by a Natural Sciences and Engineering Research Council of Canada (NSERC) Michael Smith Foreign Study Supplement.

\section{REFERENCES}

Akayezu, J. M., J. G. Linn, D. E. Otterby, and W. P. Hansen. 1994. Evaluation of calf starters containing different amounts of crude protein for growth of Holstein calves. J. Dairy Sci. 77:1882-1889.

AOAC International. 2000. Official Methods of Analysis. Vol. I. 17th ed. AOAC International, Arlington, VA.

Bach, A., J. J. Villalba, and I. R. Ipharraguerre. 2012. Interactions between mild nutrient imbalance and taste preferences in young ruminants. J. Anim. Sci. 90:1015-1025.

Baldwin, R. L., K. R. McLeod, J. L. Klotz, and R. N. Heitmann. 2004. Rumen development, intestinal growth and hepatic metabolism in the pre- and postweaning ruminant. J. Dairy Sci. 87(ESuppl.):E55-E65.

Chalupa, W., C. A. Baile, C. L. McLaughlin, and J. G. Brand. 1979. Effect of introduction of urea on feeding behavior of Holstein heifers. J. Dairy Sci. 62:1278-1284.

Cooper, S. D., I. Kyriazakis, and J. V. Nolan. 1995. Diet selection in sheep: the role of the rumen environment in the selection of a diet from two feeds that differ in their energy density. Br. J. Nutr. 74:39-54

Drackley, J. K. 2008. Calf nutrition from birth to breeding. Vet. Clin. North Am. Food Anim. Pract. 24:55-86.

Duncan, A. J., and S. A. Young. 2002. Can goats learn about foods through conditioned food aversions and preferences when multiple food options are simultaneously available? J. Anim. Sci. 80:2091-2098.

Favreau-Peigné, A., R. Baumont, and C. Ginane. 2013. Food sensory characteristics: Their unconsidered roles in the feeding behaviour of domestic ruminants. Animal 7:806-813.

Fiems, L. O., C. V. Boucque, B. G. Cottyn, and F. X. Buysse. 1985. Evaluation of rapeseed meal with low and high glucosinolates as a protein source in calf starters. Livest. Prod. Sci. 12:131-143.

Forbes, J. M. 2007. Voluntary Food Intake and Diet Selection in Farm Animals. 2nd ed. CABI, Cambridge, MA.

Gherardi, S., J. L. Black, and W. F. Colebrook. 1991. Effect of palatability on voluntary feed intake by sheep. II. The effect of altering the palatability of wheaten hay on long-term intake and preference. Aust. J. Agric. Res. 42:585-598.
Hill, T. M., J. M. Aldrich, R. L. Schlotterbeck, and H. G. Bateman. 2007. Protein concentrations for starters fed to transported neonatal calves. Prof. Anim. Sci. 23:123-134.

Howery, L. D., D. Bailey, G. Ruyle, and W. Renken. 2000. Cattle use visual cues to track food locations. Appl. Anim. Behav. Sci. 67:1-14.

Jasper, J., and D. M. Weary. 2002. Effects of ad libitum milk intake on dairy calves. J. Dairy Sci. 85:3054-3058.

Kertz, A. F., M. K. Koepke, L. E. Davidson, N. L. Betz, J. R. Norris, L. V. Skoch, B. R. Cords, and D. T. Hopkins. 1982. Factors influencing intake of high urea-containing rations by lactating dairy cows. J. Dairy Sci. 65:587-604.

Kyriazakis, I., and J. D. Oldham. 1993. Diet selection in sheep: The ability of growing lambs to select a diet that meets their crude protein (nitrogen x 6.25) requirements. Br. J. Nutr. 69:617-629.

Leonardi, C., and L. E. Armentano. 2003. Effect of quantity, quality, and length of alfalfa hay on selective consumption by dairy cows. J. Dairy Sci. 86:557-564.

Miller-Cushon, E. K., R. Bergeron, K. E. Leslie, G. J. Mason, and T. J. Devries. 2013a. Effect of early exposure to different feed presentations on feed sorting of dairy calves. J. Dairy Sci. 96:4624-4633.

Miller-Cushon, E. K., and T. J. DeVries. 2011. Effect of early feed type exposure on diet-selection behavior of dairy calves. J. Dairy Sci. 94:342-350.

Miller-Cushon, E. K., C. Montoro, A. Bach, and T. J. Devries. 2013b. Effect of early exposure to mixed rations differing in forage particle size on feed sorting of dairy calves. J. Dairy Sci. 96:3257-3264.

Miller-Cushon, E. K., C. Montoro, I. Ipharraguerre, and A. Bach. 2014. Dietary preference in dairy calves for feed ingredients high in energy and protein. J. Dairy Sci. 97:1634-1644. http://dx.doi. org/10.3168/jds.2013-7199.

Montoro, C., and A. Bach. 2012. Voluntary selection of starter feed ingredients offered separately to nursing calves. Livest. Sci. 149:6269.

Montoro, C., F. Boe, I. R. Ipharraguerre, and A. Bach. 2012. Development of a method to evaluate oro-sensory preferences in weaned calves. Livest. Sci. 150:374-380.

Montoro, C., E. K. Miller-Cushon, T. J. DeVries, and A. Bach. 2013. Effect of physical form of forage on performance, feeding behavior, and digestibility of Holstein calves. J. Dairy Sci. 96:1117-1124.

Nolte, D. L., F. D. Provenza, and D. F. Balph. 1990. The establishment and persistence of food preferences in lambs exposed to selected foods. J. Anim. Sci. 68:998-1002.

Nombekela, S. W., M. R. Murphy, H. W. Gonyou, and J. I. Marden. 1994. Dietary preferences in early lactation cows as affected by primary tastes and some common feed flavors. J. Dairy Sci. 77:2393-2399.

NRC. 2001. Nutrient Requirements of Dairy Cattle. 7th rev. ed. Natl. Acad. Sci., Washington, DC.

Provenza, F. D. 1995. Postingestive feedback as an elementary determinant of food preference and intake in ruminants. J. Range Manage. 48:2-17.

Provenza, F. D., and D. F. Balph. 1987. Diet learning by domestic ruminants: Theory, evidence and practical implications. Appl. Anim. Behav. Sci. 18:211-232.

SAS Institute. 2008. SAS User's Guide. SAS Institute Inc., Cary, NC.

Scott, L. L., and F. D. Provenza. 1998. Variety of foods and flavors affects selection of foraging location by sheep. Appl. Anim. Behav. Sci. 61:113-122.

Scott, L. L., and F. D. Provenza. 2000. Lambs fed protein or energy imbalanced diets forage in locations and on foods that rectify imbalances. Appl. Anim. Behav. Sci. 68:293-305.

Stamey, J. A., N. A. Janovick, A. F. Kertz, and J. K. Drackley. 2012. Influence of starter protein content on growth of dairy calves in an enhanced early nutrition program. J. Dairy Sci. 95:3327-3336.

Stanton, A. L., D. F. Kelton, S. J. LeBlanc, J. Wormuth, L. K. Fox, and K. E. Leslie. 2013. Effects of tulathromycin on incidence of various diseases and growth of young heifers. J. Am. Vet. Med. Assoc. 243:267-276. 
Terré, M., M. Devant, and A. Bach. 2007. Effect of level of milk replacer fed to Holstein calves on performance during the preweaning period and starter digestibility at weaning. Livest. Sci. 110:82-88.

Van Soest, P. J., J. B. Robertson, and B. A. Lew. 1991. Methods for dietary fiber, neutral detergent fiber, and nonstarch polysaccharides in relation to animal nutrition. J. Dairy Sci. 74:3583-3597.

Warner, R. G., W. P. Flatt, and J. K. Loosli. 1956. Dietary factors influencing the development of the ruminant stomach. J. Agric. Food Chem. 4:788-792.
Yearsley, J. M., J. J. Villalba, I. J. Gordon, I. Kyriazakis, J. R. Speakman, B. J. Tolkamp, A. W. Illius, and A. J. Duncan. 2006. A theory of associating food types with their postingestive consequences. Am. Nat. 167:705-716. 